UDC 94(477)(092)"18"

DOI 10.24919/2519-058X.18.226563

\title{
Andrii KHRIDOCHKIN
}

PhD (History), PhD hab. (Law), Associate Professor, Head of the Department of Law of Dniprovskyi University of the Humanities, 35 Yermolaieva Street, Dnipro, Ukraine, postal code 49033 (khridochkina@ukr.net)

ORCID: 0000-0001-9387-8864

\section{Petro MAKUSHEV}

PhD hab. (Law), Professor, Professor at the Department of Theory and History of State and Law of University of Customs and Finance, 2/4 Volodymyr Vernadskyi Street, Dnipro,Ukraine, postal code 49000 (mpv12@i.ua)

ORCID: 0000-0001-9387-8864

\section{Андрій ХРІДОЧКІН}

кандидат історичних наук, доктор юридичних наук, доиент, завідувач кафедри права Дніпровського гуманітарного університету, вул. Срмолової, 35, м. Дніпро, Україна, індекс 49033 (khridochkina@ukr.net)

\section{Петро МАКУШЕВ}

доктор юридичних наук, професор, професор кафедри теорії та історії держави і права Університету митної справи та фінансів, вул. Володимира Вернадського, 2/4, м. Дніпро, Україна, індекс 49000 (mpv12@і.иа)

Bibliographic Description of the Article: Khridochkin, A. \& Makushev, P. (2021). Vasyl Nazarovych Karazin: historic portrait against a backdrop of the epoch. Skhidnoievropeiskyi Istorychnyi Visnyk [East European Historical Bulletin], 18, 30-44. doi: 10.24919/2519-058X.18.226563

\section{VASYL NAZAROVYCH KARAZIN: HISTORIC PORTRAIT AGAINST A BACKDROP OF THE EPOCH}

\begin{abstract}
The Topicality of the Research. The topicality of the issue under study is driven by the need to carry out a smooth coverage of Karazin's biography, which presents poorly researched pages of his life. When characterizing the socio-political views of Karazin, a range of studied aspects of his worldview has been extensively extended. The Purpose of the Research. The purpose of the article is to throw light on a life journey of the prominent political and public figure, a scientist of the early $X I X^{\text {hh }}$ centuryVasyl Nazarovych Karazin, to investigate the facts and fill gaps in his biography, to outline landmarks in his life and creative activity, to analyze his fundamental scientific achievements and their importance for descendants. The Methodology of the Research. The main methods, which have been used to study the matter at issue, are as follows: chronological, historical genetic, comparative historical, historical typological, synchronous, biographic, and prosopography approaches. The Research Results. In the article there has been elucidated Karazin's biography, which provides insight into the milestones of the formation of his worldview. The authors have specified features of the social and political views of Karazin, which shaped his unique interpretation of topical political matters
\end{abstract}


concerning the form of government, role of the state authority in the development of political and ideological areas. It has determined the scope and motivation for activity of Karazin as a landowner and the founder of many non-governmental organizations of that time. The Practical Significance. The research findings can be used while investigating sources of the formation of the ideology of conservatism of the XIX ${ }^{\text {th }}$ century, a degree of its assimilation of the provisions of innovative public opinion and pattern of the use of West European socio-political theories, a role of conservative nobility in the social movement, sequence of their ideas and policy of the ruling elite.

Key words: administrative activity, inventive activity, public activity, Karazin, reformatory endeavors, peasant matter, socio-political views, Kharkiv University.

\title{
ВАСИЛЬ НАЗАРОВИЧ КАРАЗІН: ІСТОРИЧНИЙ ПОРТРЕТ НА ТЛІ ЕПОХИ
}

\begin{abstract}
Анотація. Актуальність дослідження. Актуальність досліджуваної проблеми зумовлена потребою у здійсненні рівномірного висвітлення біографії Каразіна, в якій відображені раніше недостатньо вивчені сторінки його життя. При характеристииі суспільно-політичних поглядів Каразіна значно розширено коло досліджуваних аспектів його світогляду. Мета досліджсення. Мета статті полягає у висвітленні життєвого иляху відомого політичного і громадського діяча, вченого першої половини XIX cm. Василя Назаровича Каразіна, дослідженні фактів і висвітленні прогалин в його біографії, окресленні основних віх життя і творчості, аналізі його основних наукових досягнень та їх значення для нащадків. Методи дослідження. Головними методами дослідження даної проблеми є хронологічний, історико-генетичний, порівняльно-історичний, історикотипологічний, синхронний, біографічний та просопографічний підходи. Результати дослідження. У статті висвітлено біографію Каразіна, яка відображає основні етапи формування його світогляду. Розкрито особливості соиіальних і економічних поглядів Каразіна, що зумовили своєрідність трактування ним важливих політичних питань щодо державного устрою, ролі державної влади в розвитку економічної, політичної і ідеологічної галузей. Розкриті зміст імотивачія діяльності Каразіна як помішика ізасновника ряду громадських організачій того часу. Практична значимість. Одержані у статті результати можуть бути використані при дослідженні джерел формування ідеології консерватизму XIX ст., ступеню засвоєння нею положень прогресивної суспільної думки та характеру використання західноєвропейських суспільно-політичних теорій, ролі консервативно налаштованих дворян в суспільному русі, послідовності їх ідей і політики правлячих кіл.

Ключові слова: адміністративна діяльність, винахіднищька діяльність, громадська діяльність, Каразін, реформаторські проекти, селянське питання, суспільно-політичні погляди, Харківський університет.
\end{abstract}

The Problem Statement. For a long time, Vasyl Nazarovych Karazin has not belonged to the category of those figures of national history, who are called "undeservedly forgotten" since Karazin's contribution to the development of natural sciences is well-known and widely considered, and Kharkiv University established due to his great efforts has been named after him. The time when the name of Vasyl Nazarovych was mentioned exclusively in the context of the activities of famous historical figures was irrevocably up. Nowadays, there is no doubt that he is one of those famous people, who worked for the good of homeland and were active and outstanding citizens, who were always respected by contemporaries and remain respected by their descendants. Being endowed with a talent and organizational skills, they made and have kept making their unique contribution to the advancement of society, which in turn needs their talent and diligence. Thus, a genuine interest in individual representatives of that group of unique, and most often, extraordinary persons with distinct characters, different destinies but united by a shared aspiration - to improve the welfare of the people, rectify the social life of their country and mark a place for them in the history books - is unlimited. Vasyl Nazarovych Karazin was one of such historical figures. 
The Analysis of Recent Researches and Publications. The death of V. N. Karazin in 1842 remained an event which was not particularly noticed either by academic communities or the general public. The above is primarily explained by the reputation of the very Karazin - his "political unreliability". Therefore, it was hardly accidental that the first publication dedicated to Vasyl Nazarovych appeared in 1860. It belonged to G. Danylevskyi, who published a biographic essay about his childhood and teenage years in five issues of the newspaper "Northern Bee" (Severnaya pchela) (Danylevskyi, 1860). Selective attitude towards the elucidation of Karazin's life journey is justified by the unwillingness to break the prevailing tradition of that time - "to be out" of the post-Petersburg period of his life activities. However, the publication lifted the so-called taboo to refer to the personality of Vasyl Nazarovych and his epistolary heritage, the part of which began to be introduced through the pages of individual manuscripts during the $1860 \mathrm{~s}$.

In the research papers, the address to the Karazin subject commenced at the end of the $1880 \mathrm{~s}$ and was associated with the presentation of the article by V. Loshchenkov and a two-volume contribution by V. Semevskyi (devoted to the peasant matter in the XVIIIth - the beginning of the XIXth century). By contrast with V. Loshchenkov (he considered Karazin as anadvocate of the abolition of serfdom (Loshchenkov, 1887)), V. Semevskyi didn't find grounds to regard his worldview as "anti-serfdom" (Semevskyi, 1887). Moreover, the standpoint of V. Semevskyi became predominant in the literature. Subsequently, this aspect of Karazin's worldview was either discussed or mentioned taking into account Semevskyi's view.

As a result, at the beginning of the XXth century the historical literature contained a wellformed stereotype of Karazin as a man, who defended the conservative principles that made his socio-political stance "not attractive" to the Soviet historical science.

The situation changed at the end of the 1940s. That occurred due to the kickoff of the study of his experiments in natural sciences. Hence, some publications, which mainly appeared in periodicals, reached the same conclusion: Karazin is a scientist, who was in advance of his times. However, that sort of statement in Marxist theory wasn't in line with his reputation of a follower of the monarchical power and serfdom. The solution was found in focusing on those episodes of his biography and public activity, which gave a unilateral vision of the personality of Karazin. Papers of A. Sliusarskyi, V. Kozlovskyi (Kozlovskyi, 1963), generalizing works on the history of social, sociological, philosophical thought and social movement in Russia and Ukraine kept "glorifying" Karazin.

The publication of Yu. Lavrynenko's book, which made ill-founded conclusion about Vasyl Nazarovych as the main "encourager and driver" of the liberal reforms in Russia and "nationally minded Ukrainian patriot" in the modern sense of the term, was notable in the foreign historiography of that time (Lavrynenko, 1975). I. Lysiak-Rudnytskyi, who assigned Karazin the title of the "forerunner", "pioneer" of the Ukrainian revival remaining the state patriot of Russia and a regional patriot of Sloboda Ukraine, responded to the book (Lysiak-Rudnytskyi, 1993).

Nevertheless, the Ukrainian historiography denied the reference to Karazin as a representative of the Ukrainian national revival. He was introduced as a figure, who had been subjected to political repression of the Russian government (Losiievskyi, 1993). Ya. Abramov's idea of the involvement of Karazin in the rebellion of the Semyonovsky regiment in 1820 was revived (Venhlovskyi, 1990). The focus was on those pages of his biography, which allowed presenting the socio-political views of Karazin to be similar to the principles of representatives of consistent democratic ideology of the time. Thus, the anniversary edition gathered such statements about him to accomplish the before mentioned 
goal, and the opening piece of M. Bieliaiev even emphasized a desire of "Kruchik landowner" "to root" into bourgeois relations (Bieliaiev, 1998).

The Methodology of the Research. In order to solve the research tasks, the authors have used a set of universal and special methodological principles. First of all, it has been applied the objectivity principle, which provides for directing the study on a comprehensive analysis of the worldview of V. N. Karazin and the reconstruction of his biography. The observance of the historical method has made it possible to characterize the socio-political views of V. N. Karazin, taking into account the specifics of the historical time, which differed by the varying stages of development of socio-political thought in various European countries. The compliance with the principle of multifactority, which involves studying a full range of objective and subjective factors influencing historical processes, has determined a need to analyze the ambiguous impact of different socio-political trends on the worldview of V. N. Karazin. Due to the use of the problem-chronological method of enunciating material, V. N. Karazin's convictions have been investigated through formulating the scientific problems: socio-political views and peasant matter. When writing the article, the authors also used the principle of pluralism (it considers the acceptability of several perspectives to the problem under study), a bibliographical approach (the subject matter of which is the life journey of V. N. Karazin, the formation of his personality, development of his values, worldview, character and skills) as well as prosopography approach (it has allowed reconstructing multifaceted aspects of life of the Karazins keeping in mind all factors, which affected the personality of Vasyl Nazarovych).

The Purpose of the Research. The purpose of the article is to throw light on a life journey of the prominent political and public figure, a scientist of the early XIX ${ }^{\text {th }}$ century Vasyl Nazarovych Karazin, to investigate the facts and fill gaps in his biography, to outline landmarks in his life and creative activity, to analyze his fundamental scientific achievements and their importance for descendants.

\section{The Basic Material Statement.}

Formation of V. N. Karazin's Worldview. The progenitor of the Karazin line is considered to be Vasyl Nazarovych's great-grandfather - Hrihorii Karadžić, who was the archbishop of the Bulgarian city Sofia for a long time (Khridochkin, 2001). Grandfather of Karazin Oleksandr Hryhorovych was a native of Serbia - changed not only the place of residence of the family but also the type of his professional activity - he became a serviceman. It was then that the name of Oleksandr Karadžic was recorded in the documents as Karazin (Karazin, 1910). It is known that Oleksandr Karazin died in 1753 in Rublivka village in Kharkiv region. Father of Vasyl Nazarovych, Nazar Oleksandrovych, was of Greek origin on his mother's side. He was fluent in Greek and Turkish and inherited the profession from his father - he also became a serviceman. Nazar had to take part both in the Seven Years' War and the Russo-Turkish War (1768 - 1774). Nazar resigned his commission in 1770 having the rank of a colonel. On November 19, 1770, he granted the right of perpetual use of two Ukrainian villages in Kharkiv region: Kruchik (47 farmsteads) and Osnovyntsi (35 farmsteads) of the Krasnokutsk Commissariat. There he married Varvara Yakivna, a representative of one of the ancient Cossack families, the daughter of sotnik (a lieutenant of the Cossack troops) of Kharkiv regiment Yakov Ivanovych Kovalevskyi, future mother of Vasyl Nazarovych. On January 30, 1773, Vasyl Nazarovych Karazin was born in a farm house in Kruchik village (since a parents' house had not been finished yet) (Bolebrukh, Kudelko, Khridochkin, 2005).

Vasyl spent his childhood in the bosom of his family. The conditions of upbringing of Karazin and his environment as well as friends of his family could influence the choice of 
several options for his future or professional career. He saw the life of an ordinary Ukrainian estate, grew up surrounded by peasant children and communicated with serfs. At the same time, he witnessed a conflict between his father and a neighbor landlord due to a land plot they both wanted to own. In other words, Vasyl was brought up from a young age as the owner of the estate, which he would inherit from his father (Abramov, 1891). Moreover, he constantly listened to his father's stories about the wars he directly participated in, the lives of his Serb ancestors, who had been regularly fighting with Turkey for their national liberation. Under the conditions of the respected authority of Nazar Oleksandrovych, his son had a natural desire to become a soldier.

After the death of Nazar, the family found itself in a financial squeeze, as the widow had to survive with two sons Vasyl and Ivan, who was only four years old at that time. Varvara Yakivna had to reach out to Count Ivan Mykhailovych (his name, unfortunately, wasn't identified) - the patron of the Karazins to whom Nazar Oleksandrovych had addressed with various requests. It's most likely that due to his support, as well as under the auspices of people, who knew Vasyl Nazarovych's father well, the boy was enrolled in private boarding schools for noble children: the former - named after H. Fielding in Kremenchuk, and the latter - named after J. Schultz in Kharkiv. Unfortunately, a record of Vasyl Karazin's stay in those education institutions has not been kept (Sliusarskyi, 1955). However, there is no doubt he didn't betray his childhood dream - to be a military man - and shortly seized a chance.

During a trip of the Little Russia Governor-General Count P. Rumyantsev-Zadunaisky through Kharkiv, V. N. Karazin turned to him with "a request" to study military science. At his time, the count had served in the army with Vasyl's father (Stanchev, 2005), therefore, he helpfully enlisted the young man in the Cuirassier Regiment, which he headed. Within a short period of time, through Rumyantsev-Zadunaisky's help once again, the surname of Karazin was included in the list of the Semyonovsky Lifeguard Regiment, where he was never seen for five years. It is known that the "Manifesto on the Liberty of the Nobility of 1762" of Peter III freed representatives of the Russian nobility from its obligatory service to the state. However, according to the tradition established since Peter's times, many young people, who were deeply concerned with the idea of serving their country, wore military uniforms or embarked upon official careers in various government agencies.

Karazin was one of those young men and, thus, on January 22, 1791, he arrived in St. Petersburg and joined the Semyonovsky Regiment, an elite unit of the Russian army, having the rank of a sergeant. During the reign of Catherine II, guards were not burdened with military concerns and had enough free time, which they used at their discretion. Karazin spare no efforts for education and self-education. He regularly attended lectures at St. Petersburg Mining Corps, one of the best education institutions in Russia at that time. There he studied not only Mathematics, Physics, Chemistry but also foreign languages, Poetry, Political Economy and other sciences. He gained profound knowledge in natural sciences and humanitiesand mastered Latin, German, and French, which later came in handy to him.

The training at the Mining Corps was a period of V. Karazin's acquaintance and communication with different extraordinary people, for instance, with V. Kapnist, M. Karamz in and the others, including foreign scientific literature. In general, the years in Petersburg can be considered as an important stage of the formation of Karazin as a personality. It was the time of big changes in his worldview (Berkovych, Hurevych, Stashevskyi, 1953). After, he wasn't interested in the military career. On the one hand, it was caused by Vasyl Nazarovych's insight into various sciences and common disenchantment with that kind of 
military service, which drastically contrasted with his childish vision of it. On the other hand, Karazin found himself in the entirely different environment.

The society became engaged in socio-political issues in the light of the familiarity of educated citizens of the country with the works of Western European thinkers. Thus, the interest in public affairs predominated. He was primarily concerned about the issues of serving the country. Therefore, he traveled through Russia and Ukraine for three years (from 1792 to 1795 ) trying to understand the state of society and public affairs. It is possible that after the trip, Karazin decided to come to grips with the problems of the peasantry. When he returned home, he thought about how to realize his intention. In particular, to improve relations with peasants, Karazin established the Village Council, a body controlling estate affairs with the direct participation of farmers. He made up his mind to establish a foothold in Kruchik (Posokhov, 2015). Apparently, the decision was quite conscious because, contrary to plans of his relatives, he married Domna Ivanivna, a serf, an apprentice of his mother. Such an unexpected step of Vasyl Nazarovych frayed relations with his family.

Despite quite long absence of Vasyl Nazarovych in St. Petersburg, his name still was in the list of guardsmen of the Semyonov Regiment he got paid an officer's salary for all that time. It is known that one of the first orders of the young Emperor Paul I required the arrival of all the nobles at the duty area they belonged to. Karazin most likely did not want to come to St. Petersburg, and thus, he was deprived of both the rank of an officer and an additional source of income. It is obvious that after, he did not feel comfortable enough in his homeland; hence he decided to leave the country for a while. On June 23, 1798, he sent a letter to the emperor, whereby he asked for an exit permit referring to health condition.

However, the issuance of foreign passports was suspended at that time, and Karazin concluded to flee (Uzbek, 2002). Vasyl Nazarovych and his pregnant wife, who gave in a long tripand died while giving birth, reached the border through Pskov, Riga, and Mitau. Near the border, Karazin hired four guides to help him cross the border. All his endeavors went down the drain: on the night of August 13, 1798, he was arrested. All attempts to bribe border guards failed, and a dispatch about the detained escapee was sent to St. Petersburg. In the existing situation, Karazin definitely would subject to imprisonment in the Shlisselburg Fortress but he didn't lose his head and sent a letter to Paul I, trying to be ahead of the report.

His Highness was surprised by two things in that letter: firstly, why did not Karazin mention his illness, which required the stay at the seaside?; secondly, why did he "scare" the emperor that in case of "a tough sentence", the requester, who implored quarter, would fully realize the justification of hostility to the imperial power? Anyway, in Karazin's position, such negligence was understandable. However, nobody can tell, perhaps it was "extravagant" carelessness that attracted the attention of the emperor and the unpredictable Paul I turned anger into mercy.

It is apparent the message reached the recipient. Indeed, it is difficult to say what Karazin hoped for and whether he assumed that further events would develop in that way, but he visited the emperor; after a long conversation Vasyl Nazarovych got tenure in the state treasury. Moreover, based on the decision of the Senate as of February 3, 1800, V. N. Karazin was appointed to a post of translator at "the office of the state quaestor" and a chief director of baron Vasyliev". A year later (on January 22, 1801) he obtained the rank of collegiate assessor for collecting materials on the history of medicine and finance.

The literature ambiguously states the grounds of Karazin's escape abroad. It seems possible to say that the "cruelty" of the reign of Paul I was hardly observed in remote Kruchik (Kudelko, Vovk, 2013). An explanation of some of the real reasons for those unsuccessful 
travels can be found in the document "Personal information" as of October 1, 1798, written under the enrolment in the civil service.

Thus, the childhood habit of solitude, office silence with favorite books, reflections on a man and the world during walks in the grove, philosophism, as well as poor health, led to the fact that his dream of military service dimmed; the stay in St. Petersburg, relations with progressive youth adjusted Karazin's views to the West, to his perfectly organized society, education, beauty of nature. Consequently, there Karazin hoped to find a niche for himself and his abilities and scientific aptitudes (Trefylev, 1910). These two reasons were heavily strengthened by love peculiar to 25-years-old young man. He loved his Domna very much, who wasn't welcomed by his relatives, and their painful "reproaches" eventually forced Karazin to take a decisive step: to sell the estate on extremely disadvantageous terms and, as it is said, to follow with his love their noses.

The treatment on the coast was one of the motives for the foreign "tour" that is why Karazin did not dare, as the authors believe, to talk about it as his primary goal in a sincere request to the emperor dated August 30,1798 - the others could be revealed... The official application for an international passport was quite another matter.

Hence, at the age of twenty-eight, Vasyl Nazarovych Karazin managed to achieve such a status in St. Petersburg high society that a representative of a provincial noble family could not even think of. His childhood dreams of a military career, which would most likely be realized due to father's contacts, were driven out, primarily, by the desire to receive a decent education abroad and then, by the opportunity to become an equal member of the capital's nobility, which jealously kept watch over the rapid career progression of the countryman. New perspectives, which opened up to V. N. Karazin, literally, captured him completely, and the only thing he worried about at the time was the position at the royal court.

Activities of V. N. Karazin in administrative and public positions. There is no doubt Vasyl Nazarovych was well-informed about the capital ambience as evidenced by the fact that he smoothly faced another change of the Russian emperor. Paul I was assassinated on the night of March 12, 1801, due to a conspiracy carried out by a small group of people, and one of his sons - Alexander - succeeded to the throne. Karazin, probably, heard something about the conspiracy, so he was ready for the inevitable in his way. On March 12, Vasyl Nazarovych had a prepared letter addressed to the new autocrat. The addressee received the letter ten days later but the content of that anonymous, in the words of Karazin, "political catechism" (Karazin, 1910) was of great interest to the tsar, because the letter to the successor was very consistent with the first Manifesto of Alexander Pavlovych. In his message, Karazin touched upon the need to reform the monarchy, to establish "other laws" in the country, to regulate peasant duties, etc. The search for the letter's author did not require high effort: natives of Ukraine D. Palen and I. Troshchynskyi were familiar with Vasyl Nazarovych's handwriting well, so in early April Karazin was introduced to Alexander I. This meeting, apparently, did not disappoint the emperor and resulted in the permission of His Majesty for Vasyl Nazarovych to "talk to him similarly open and write "private and confidential". Karazin was pleased to take advantage of the offer and sent two detailed notes and as many as ten letters to the emperor for three years. They brought forward his proposals relating to the issues of the state and local government, reorganization of the court system in the country, foreign trade, the causes of the devaluation of karbovanets, and the future of state peasants and much more (Vovk, 2016).

Karazin's success story was going on. On April 21, 1801, by the personal order of the emperor, he was transferred to the department headed by D. Troshchynskyi, a compatriot 
of Karazin, and awarded a ring "for collecting materials on the history of finance". Vasyl Nazarovych kept making new friends: he got acquainted with Speranskyi M. and O. Radishchiev, became an active member of the literary circle of the latter at the meetings of which he presented his poems, studied the manuscripts of Oleksandr Mykolaiovych. Karazin's position among the capital nobility turned to be more steady - people, who suffered during the reign of Paul I were rehabilitated at his request.

One of the manifestations of trust of Alexander I in V. N. Karazin was the instruction to investigate the abuses of Kaluga Governor Lopukhin, who distinguished by "an outrage upon justice", bribery, and other "dishonest cases". Karazin conducted an in-depth analysis of charges, most of which were confirmed, and conveyed inspection results in a reporting notice to the emperor.

Vasyl Nazarovych also found his job in the government sector, which was being developed, as the beginning of the reign of Alexander I was characterized by attempts of the young emperor to update the system of state bodies of Russia. According to one of his Manifestos issued on September 8, 1802, ministries were formed instead of collegia. Thus, Karazin was appointed to the position of a "chief" of the "Commission on Schools" established under the Ministry of Public Education. The commission he headed had a key role in carrying out the reform of enlightenment, which was aimed at strengthening the centralization of education management and ensuring the consistency of curriculums of institutions of different degrees (Honcharuk, 2012). "Preliminary rules of public education" were prepared with direct involvement of Vasyl Nazarovych, and he compiled "Gymnasium general concept". Karazin's merits did not go unnoticed: on September 22, 1802, he was awarded the Order of St. Vladimir "for particular efforts to draft new statutes" for educational institutions of the Russian Empire.

Activities of V. N. Karazin at the superior position at the "Commission on Schools" and in the field of reforming higher, primarily, university education were fruitful as well. In addition to the change of the status of universities (each of them was to become the principal institution of the created educational districts), at the beginning of the XIXth century their number increased - universities were opened in Dorpat, Vilno, and Kazan. Kharkiv University is an exception among them as it was not only the first established in the Ukrainian lands, which were part of the Russian Empire, but also the first educational institution opened not by government decision but thanks to the initiative of patriotic representatives of the Ukrainian community, whose interests were expressed by Vasyl Nazarovych Karazin.

During two years he was literally crazed about the idea of establishing the university at the territory of Sloboda Ukraine. Scrambling between St. Petersburg and Kharkiv, Karazain achieved the emperor's signing of a decree to open the university, organized several fundraising to support the establishment of the educational institution, donated his funds due to underfunding to prepare facilities and buy necessary equipment, invited foreign experts to work at the university, etc. Unfortunately, Karazin never succeeded in accomplishing business commenced by him and organized for completion.

On August 24, 1804, Karazin resigned having a rank of a state councilor. The reason wa sblaming him in June of the same year for "wasteful expenditure of public funds", which he had been allocated for the purchase of prints and "hiring craft specialists" (Vovk \& Kudelko, 2015). The above led to "severe reproof" and deprivation of the right to intervene in affairs of the education establishment. This episode was very likely a formal cause to call time on his career as a civil servant. In the words of Karazin, from the end of 1802 he felt another attitude 
to himself both on the part of the entourage of the Emperor Alexander I and St. Petersburg nobles. The emperor refused to have personal meetings with Vasyl Nazarovych and forbade entering into any correspondence with him. One can assume that he had a good look through Karazin's political views and quitted considering them to be attractive. The imperial entourage changed its attitude towards Karazin by limiting the number of documents of the Ministry of Public Education he was authorized to work with; there were "misunderstandings" with the Minister P. Zavadovsky. The nobles resorted to insults and "false rumors".

It is difficult to say what Karazin expected when he submitted his resignation "for health reasons" on August 11. Probably, he was under the influence of an emotional impulse, although he had no other way. The order states: "to dismiss Karazin, the head of the central office of schools from the post of collegiate councilor, awarding him the rank of state councilor".

Karazin attempted to remain in the civil service, proposing himself as Russian emissary on Balkan affairs, who was to help the Serbian rebellion, which had broken out in Serbia and was directed against dependence on Turkey. At the same time, in the letter to the Foreign Minister, Prince A. Czartoryski, he wrote about the need for immediate negotiations between the Russian state and the Turkish government on granting the Serbian population autonomy. He was confident that the content of his message would become known to the emperor, so he turned to his feelings.

However, it seems he generated that sort of plan during personal communication with many public figures of Serbia, including Todor Filipovic, the future author of the draft of the state system of Serbia whom Karazin invited to work at Kharkiv University. Moreover, the striking similarity between Karazin's idea of the "Kingdom of Slovenes" and the project of establishment of "Slavic-Serbian Kingdom" by Stratimirovic and the demands of the leaders of the Serbian uprising catches the attention (Denysenko, 2007). The most interesting is that the message of Karazin to A. Czartoryski coincided with the arrival of deputies from the insurgents in St. Petersburg in the autumn of 1804.

Thus, the "hard-fought" idea of Vasyl Nazarovych turned no more than a year and a halfin November 1804. Therefore, there is every reason to believe that Karazin, insisting on immediate assistance to the Serbs and knowing that the Serbian ambassadors asked the Russian government to send them a "Russian parliamentarian" to negotiate with Turkey, nominated himself for this role.

The resignation from the Ministry of Public Education was very painful for Karazin. He did not notice a point when excessive activity and self-confidence led to the dissatisfaction among the Minister of Education and his inner circle, and friendly relations with the emperoramong the stately nobility. Consequently, severed ties with Alexander I, resignation from the Ministry of Public Education, a ban on interfering in the affairs of his offspring - Kharkiv University - meant the collapse of all the life plans for Karazin, the loss of the opportunity to be useful to the Fatherland. These sentiments were expressed in a letter to A. Czartoryski dated November 21, 1804. Running for the liberation of the Serbs from the Turkish yoke, Karazin wrote that his father had repeatedly risked his life in the war for this very reason.

When the last-chance effort to remain in the civil service failed, Karazin had no choice but to return to Sloboda Ukraine. Having come to Kruchik, over a time necessary to get used to a completely different ambience and, perhaps, serious reflection, Karazin decided not only to regulate his financial standing but also to solve the complex agrarian-peasant problem, which troubled the society of that time. Thus, Kruchik village in Sloboda Ukraine turned into a kind of experimental site. 
V. N. Karazin - a landowner of Kruchik village. Having faced the village reality, Karazin found out that it was far from great. Vasyl Nazarovych came to grips with reorganizing the management of his estate. He recommenced the operation of the Village Council, which he had established before his departure to St. Petersburg. In his idea, its functioning had to cultivate the peasants' faith in the "just" power of a landowner. Karazin maintained that kind of faith in the minds of the peasants through introducing elements of peasant self-government with the obligatory control of the landowner.

After the return of V. N. Karazin to Kharkiv region, his life evolved a period of extremely fruitful research activities in various fields of science and, especially, in those which closely related to agriculture. The presentation of his invented device "for wine distilling", which was assessed as an "advance in distillation", in the Council of Moscow University at the beginning of 1806 can be considered as his baptism under fire (Pyrih, 2014). And two years later, he demonstrated a "light" version of his invention in the Society of Naturalists. After another two years, he introduced an effective means of producing nitrate. In 1810 Karazin established a meteorological station in Kruchik, which became the first in Ukraine. However, this happened after the release of Vasyl Nazarovych from the second arrest in his life.

The fact is that Karazin, even in Kharkiv village, keep monitoring foreign and domestic policy developments attentively. Although the news reached Kruchik late, Vasyl Nazarovych was well up in the major European events, knew about the state of affairs and the public sentiments in the country, and the failures of the Russian army in the fight against Napoleon (Khridochkin, 2001). He diligently recorded his observations and considerations in a diary and continued to share some of them with the emperor from time to time. In one of such letters he offered the Russian government a kind of interpretation of the international neutrality policy. From his perspective, Russia had to break diplomatic relations with all states without exception, return the armed forces from abroad and focus on the development of industry, agriculture, and public administration reform.

As a rule, the monarch ignored his numerous messages, but he did not delay to respond to this one and the reaction of Alexander I was very sharp. He ordered "to detain" Karazin at "Kharkiv City Military Prison" for eight days and have his written undertaking not to disturb His Majesty with "bold papers".

The arrest and another ban on sending letters to Alexander I influenced Karazin, and until 1820 he did not dare to violate the emperor's order. However, he did not give up attacking government officials with his projects and proposals. He got under V. Kochubey's, the Minister of Internal Affairs, skin the active "correspondence" with whom V. N. Karazin began with the announcement he had founded the Philotechnical Society in Kharkiv in 1811. Under the framework of the established organization, he not only performed managerial functions in good faith but also conducted intense research activities. Even a short list of problems Karazin bothered with demonstrates the scope of his interests and tireless practical activity. He was engaged in breeding new varieties of cereals traditional for Ukraine, sought to grow rice, maintained extending potato-growing area (Tykhoi, 1905). On his experimental area, he managed, according to him, to grow a poppy stalk, which had fifty branches and a millet bush with thirty branches. Karazin produced chemical fertilizers, and presented a threshing unit, which made it possible to squeeze nut and hemp-seed oils, for consideration of members of the society. He built a chemical laboratory equipping it with an autonomous heating system. His saltpeter and distillation plants in Kruchik manufactured dyes and cement, and a means of drying wood using steam was developed. Karazin's embalming experiments were successful enough. 
Fruitful activity of Vasyl Nazarovych as an organizer and a scientist did not go unnoticed by the government: on April 13, 1815, he got a certificate of acknowledgement, and on August 20 another one. The last recognition of Karazin's merits as the head of the Philotechnical Society was an invitation to St. Petersburg to make a report and get one more honorary mention.

That said, Vasyl Nazarovych reckoned on a different outcome. By sending reports on the activities of the Philotechnical Society to the Minister of Internal Affairs systematically, he had high hopes, first, on state financial support and, second, granting his organization the nationwide significance (Khridochkin, 2001). These dreams never came true.

Due to the endeavors, Karazin managed to get into the government's graces: he was again appointed to the Ministry of Public Education, moved to St. Petersburg where he found himself in a tumultuous political life as before and, trying to take the most active part in it, responded to major, in his perspective, political events. In particular, V. N. Karazin had never had doubts about the practicality of his idea of "improvement" of serfdom but, in those days, he began to think about extending his Kharkiv and Moscow-area experience to the entire state. Therefore, in April of 1820 he attempted to organize the "Society of Good Landlords, or Friends of the Fatherland", as reported by the Minister of the Interior, by submitting a relevant draft to him.

Vasyl Nazarovych got in on the act in the political events of the Russian capital. He was already a well-known person in St. Petersburg circles. Thus, Karazin joined the Free Society of Lovers of Russian Literature in the latter half of 1818 and on December 29 he was elected the vice-president of the organization. His activities became more intense and contributed a lot to the organization's division into two ideological wings. On March 1, 1820, he gave a report at the meeting, promoting an idea of the need to create original domestic culture and criticizing some contemporary poets for the imitation of foreign authors. Moreover, pondering on the development of literature trends, he associated this process with the political matters emphasizing the relevance of censorship (Nikolaienko, 2004).

That kind of statement was enough to put many progressive figures of the "academic republic" against him. Besides, the speech of Vasyl Nazarovych caused fierce and protracted discussions, and the difference between views was so crucial that Karazin and his soulmates left the meeting room on March 15, 1820.

It is unlikely that such visceral opposition emerged due to Karazin's thesis about the need to advance original national literature. It is possible the controversy was sparked by the piece of his speech which touched upon not the literature issues but political problems (Abashnyk, 2012). Unfortunately, it is challenging to conclude about what Karazin said during the war of words, but there was another reason for Karazin's break with the society. As evidenced by the minutes of the meeting dated March 15, Vasyl Nazarovych provided the head of a particular office of the Ministry of Interior with texts of his speeches, as well as testimonies very unfortunate for the members of the Free Society. In addition, during the period from March to June, Karazin systematically sent several letters to the Minister of the Interior informing him of the state of affairs in the Society of Lovers of Literature.

Consequently, both Karazin's "divisive" activities at the Free Society of Lovers of Russian Literature and his relations with the government dangerous for the members of the organization made the affiliation of Vasyl Nazarovych to the society unwelcome. In the minds of many public figures, he was an ordinary informer after all.

On the other hand, in the letters addressed to the Minister of the Interior Vasyl Nazarovych was also concerned about the necessity to wrap up the "misfortune of the people" and eliminate military settlements in the country, pointed to the perniciousness of excessive admiration for 
all foreign trends, called on the autocracy to "guide" the nobility to seek ways to "improve the fate of the peasants" in a nuanced way and advised to reform the financial and judicial systems; it allows one to speak about him not as an ordinary informer but as a man who was primarily anxious about the fortune of his country and who followed the desire to be useful to it.

In fact, Karazin's striving to be in the thick of political life, his sometimes excessive initiativeled to the third arrest in his life, which happened in early 1821. This time Vasyl Nazarovych was mistakenly arrested on suspicion of authorship of a leaflet seen in the barracks of the Semyonovsky Regiment, which arose in October 1820 . The search carried out by the very police head found out a large number of papers. The conclusion reached can be formulated as follows: Karazin had nothing that would indicate his direct participation in the Semyonovsky events or the authorship of the proclamation; at the same time, among the papers of Vasyl Nazarovych there were detected several records in which he covered the October events of 1820 . Kochubey didn't dare to come to stand up for him (however, he knew for sure that Vasyl Nazarovych had not written that leaflet), and Alexander I decided to seize the occasion to penalize Karazin, who had violated the flat ban once again and sent a letter to the emperor in April 1820.

Vasyl Nazarovych was not a person inclined to report. Although, being under investigation, during interview she tried to justify himself against the charges and listed the names of people who, in his opinion, "deserved" the right to be in his shoes much more than he did. He called names, apparently, "for getting that even the mention of a particular person during a conversation with the police chief could turn into denunciation regardless of the desire of the speaker. Then fate did not just mock - it treated him with a high hand, and Karazin became a victim of unfavorable circumstances. His remission was indirect confirmation of the application of "disciplinary measures" to Vasyl Nazarovych. On May 21, 1821, Karazin was going to be sent from Shlisselburg to his Kharkiv estate and placed under the supervision of Bohodukhiv Zemstvo Governor (Bolebrukh 1987). Although, the accusation of authorship of Semyonovsky proclamation was not officially dropped; it was 1839, three years before his death, when Karazin was allowed to live in any city except St. Petersburg and Moscow, which he was forbidden to visit forever.

Deprived of the opportunity to participate in the socio-political life, Vasyl Nazarovych had to seek consolidation in science. His research work was multifaceted, and his contribution to science was strong. One can only wonder how many scientific advances and discoveries this undoubtedly talented scientist would have made if he had given his mind whole to exploratory activity (Bereziuk, 2003). The exceptional practicality of his experiments and research, which definitely could have - upon condition of their refinement and manufacturing application - a tangible economic effect, is noteworthy.

The beginning of the 1830 s was marked by failed harvest in the villages, and thus, peasants were forced to turn to the wildlife fruits, including acorns, to not starve to death. Karazin studied their composition and found the way to extract the essential nutrient in order to bake "delicious and healthy bread". Vasyl Nazarovych worked at improving the methods of planting potatoes and watermelons and maintained increasing the crops of such vegetables like turnips, carrots, beets, and the others. At his estate, he conducted sericulture research, made drugs and extracts of medicinal herbs which allowed treating nervous disorders. Despite his advanced age and poor health, Karazin explored the Orel coast looking for healing springs.

The lifting of the ban on his free movement gave a new impulse to the scientific activities of Vasyl Nazarovych. In 1839 Karazin began searching for ways to update horticulture and viticulture in the Crimea (Maistruk, 2014). Vasyl Nazarovych also delved into humanities, 
in particular, history. Thus, he demonstrated his vision of history of Sloboda Ukraine by consistently interpreting its events from the nobleman's point of view. Confirming his role of an advocate of education, Vasyl Nazarovych routinely conducted classes at Kruchik School, which he had founded once upon a time.

Extremely intense research activity of Karazin gave him a certain authority in the world of science. He was an honoured and corresponding member of seven scientific societies of the Russian state. At different period of time he was elected a member of the academic boards of Moscow and Kharkiv universities, Moscow Society of Naturalists, the Society of Russian History and Antiquities, the Free Economic Society, and the Free Society of Lovers of Russian Literature. Vasyl Nazarovych was deeply involved in science until his death, which befell him during a scientific inquiry in the field of improving distillation in the south of Ukraine where he visited with one of his sons - Philadelphus, who served under command of the Commander-in-Chief of the Black Sea Fleet Admiral Lazarev in Mykolaiv. In October 1842, Karazin travelled by relay to Kharkiv region, to Kruchik. On the way home he got wet during the foul weather, caught a cold, fell ill and returned to Mykolaiv where he died on November 4, 1842, in his son's house. Vasyl Nazarovch was buried in Mykolaiv cemetery in a place of a new family burial of the Karazins. Thus, at the age of sixty-nine, Vasyl Nazarovych Karazin breathed his last.

The Conclusions. The thread of life of Vasyl Nazarovych Karazin was active enough. $\mathrm{He}$ is remembered by contemporaries and descendants as a brain box man, an outstanding inventor, public figure, advocate for the improvement and development of the education system, a very energetic and enterprising person. Having received a good education, Vasyl Nazarovych worked at the Ministry of Public Education, headed one of its committees, was the founder of Kharkiv University, which has been named after him, and taught at Kruchik school established on his initiative.

Karazin is known as a public figure; moreover, he was distinguished by a compulsive drive to be always in the thick of events of the socio-political life. For this very reason, he took an active part in the activities of various non-governmental organizations and frequently commenced the formation of new associations. Karazin always sought to respond to significant, in his view, events of public and political life by sending letters and his numerous projects to the emperor and influential government leaders. In his letters, he drew attention to the arbitrariness of ministerial officials, indifference, bureaucracy, bribery, which prevailed in the state apparatus, landlords' lawlessness in relation to serfs.

Many people criticized Vasyl Nazarovych both during lifetime and after his death. This is explained by his negative personality traits - snobbery, overconfidence, arrogance, sometimes disregard of others - which were noted by people who dealt with him. These traits were especially evident during Karazin's service in the ministry when he tried to enter the emperor's office without an invitation in plain view of the nobility surprised by the provincial's impudence, or when he aspired to join literary evenings in the imperial palace the entrance to which was only for a narrow circle of "the elite". However, there is no doubt that until his death, Vasyl Nazarovych Karazin was bounded up in the interests of society despite the strokes of bad luck.

Acknowledgement. The authors of the article are sincerely grateful to all members of the editorial board for the advice provided during doing the research and writing the article.

Financing. The authors did not receive any financial support for doing the research and writing the article. 


\section{BIBLIOGRAPHY}

Abashnik, V.A. (2012). Filosofsko-pravovye vzghliady V. N. Karazina (1773-1842) [Philosophical and legal views of V. N. Karazina (1773 - 1842)]. Hrani, 6 (86), 21-24. [in Russian]

Abramov, Ya. V. (1891). V. N. Karazin. Ego zhizn i obshchestvennaia deiatelnost [V. N. Karazin. Self-life and social activity]. St. Petersburg, 96 p. [in Russian]

Bereziuk, N. M. (2003). Slid dobryi i vichnyi na zemli Slobozhanskii: (Ivan Nazarovych Karazin ta yoho nashchadky) [A good and eternal trace on the Slobozhanska land (Ivan Nazarovich Karazin and his descendants)]. Universytety - Universitates, 2, 26-33. [in Ukrainian]

Berkovych, Z. S., Hurevych L.Y. \& Stashevskyi, V. L. (Comps.) (1953). V. N. Karazin 1773 1842: Biobibliohrafiia [V. N. Karazing 1773 - 1842: Biobibliography]. Kharkov, 76-77. [in Russian]

Bieliaiev, M. (1998). V. N. Karazin: storinky zhyttia ta diialnosti [V.N. Karazin: pages of life and work]. Vasyl Nazarovych Karazin v otsinkakh suchasnykiv i nashchadkiv. Kharkiv, 11. [in Ukrainian]

Bolebrukh, A. H. (1987). Do kharakterystyky svitohliadu V. N. Karazina [To characterize the V. N. Karazin's worldview]. Ukrainskyi istorychnyi zhurnal, 8, 85-95. [in Ukrainian]

Bolebrukh, A. H., Kudelko, S. M. \& Khridochkin, A. V. (2005). Vasyl Nazarovych Karazin (1773 - 1842): monohrafiia [Vasyl Nazarovich Karazin (1773 - 1842): monograph]. Kharkiv: Vydavnytstvo "Avto-Enerhiia", 348 p. [in Ukrainian]

Danylevskyi. H. P. (1860). Vasylyi Nazarovych Karazyn: materyaly dlia biohrafii [Vasily Nazarovich Karazin: materials for a biography]. Severnaia pchela, 24-26, 29, 30. [in Russian]

Denysenko, A. (2007). Zlety ta padinnia Vasylia Karazina [The Vasily Karazin's rise and fall]. Pamiat stolit, 4-5, 195-213. [in Ukrainian]

Honcharuk, T. H. (2012) V.N. Karazin (1773 - 1842 rr.) ta Odesa: do istorii zviazkiv zasnovnyka Kharkivskoho universytetu ta "Novoi Palmiry" [V. N. Karazin (1773 - 1842) and Odessa: to the history of relations between the founder of Kharkiv University and "Novaya Palmyra"]. Intelihentsiia $i$ vlada. Seriia: Istoriia, 26, 148-158. [in Ukrainian]

Karazin, V. N. (1910). Sochinenyia, pisma i bumagi V. N. Karazina: sobrannye i redaktirovannye prof. D. Bagaliem [Essays, letters and papers of VN Karazin: collected and edited by prof. D. Bagaliy]. Kharkov: Tip. Zylberberh i synovia, 947 p. [in Russian]

Khridochkin, A. V. (2001). Istoriko-politicheskie predstavlenyia V. N. Karazyna [Historical and political views of V. N. Karazin]. Hrani, 4 (18), 54-58. [in Russian]

Khridochkin, A. V. (2001a). Zhyttia ta diialnist V. N. Karazina [Life and work of V.N. Karazin]. Humanitarnyi zhurnal, 7, 110-115. [in Ukrainian]

Khridochkin, A. V. (2001b) Krestianskii vopros v traktovke V. N. Karazina [The Peasant Question in V.N. Karazin's interpretation]. Hrani, 5-6 (19-20), 73-77. [in Russian]

Kozlovskyi, V. I. (1963). Pytannia rozvytku vitchyznianoi promyslovosti v pohliadakh V. N. Karazina [Issues of domestic industry in the V.N. Karazin's views]. Pytannia sotsialistychnoi ekonomiky i yii narodnoho hospodarstva, 242-260. [in Ukrainian]

Kudelko, S. M. \& Vovk, O. I. (2013). Vasyl Karazin bilia vytokiv formuvannia ukrainskoi naukovotekhnichnoi intelihentsii [Vasyl Karazin at the origins of the formation of the Ukrainian scientific and technical intelligentsia]. Ukrainoznavchyi almanakh, 14, 190-193. [in Ukrainian]

Lavrinenko, Yu. (1975). Vasyl Karazin. Arkhitektura vidrodzhennia: Materialy i dumky do 200-littia z dnia narodzhennia. 1773 - 1973 [Vasily Karazin. Revival Architecture: Materials and Thoughts for the 200th Anniversary of His Birth. 1773 - 1973]. Miunkhen, 192 p. [in Ukrainian]

Loshchenkov, V. (1887) V.N. Karazin kak pomeshchik sela Kruchik [V. N. Karazin as landowner of the village Kruchik]. Kharkovskyi sbornik, 53-64. [in Russian]

Losyevskyi, Y. (1993). Russkaia lira Ukrainy: Russkie pisateli Ukrainy pervoi chetverti XIXv. [Russian literature of Ukraine: Russian writers of Ukraine in the first quarter of the XIX century]. Kharkov, 200 p. [in Russian]

Lysiak-Rudnytskni, I. (1993). Karazin i pochatky ukrainskoho vidrodzhennia [Karazin and the beginnings of the Ukrainian revival]. Istorychni ese. In 2 vol. Kyiv, Vol. 1, 530 p. [in Ukrainian]

Maistruk, O. N. (2014). Soderzhanie i osnovnye napravleniia nauchno-prosvetitelskoi i upravlencheskoi deiatelnosti V. N. Karazyna $(1773$ - 1842) [The content and main directions of 
scientific-educational and managerial activities of V. N. Karazin (1773 - 1842)]. Zhurnal nauchnykh publikatsyi aspyrantov $i$ doktorantov, 6 (96), 135-138. [in Russian]

Nikolaienko, N. O. (2004). Derzhavnytski kontseptsii V. N. Karazina [The V. N. Karazin's state concepts]. Suchasna ukrainska polityka: Polityky i politolohy pro nei. Kyiv-Mykolaiv, 100-104. [in Ukrainian]

Posokhov, S. Y. (2015). "Neponiatnyi” vs "neponiatyi” V. N. Karazin: kommentarii, remarki, apologia ["Incomprehensible" vs "incomprehensible" V.N. Karazin: comments, remarks, apology]. Dialog so vremenem: almanakh intellektualnoi istorii, 51, 64-93. [in Russian]

Pyrih, P. V. (2014). Velykyi uchenyi i reformator Vasyl Karazin (do 240-richchia vid dnia narodzhennia) [The great scientist and reformer Vasyl Karazin (to the 240th anniversary of his birth)]. Siverianskyi litopys, 1-3 (115-117), 184-187. [in Ukrainian]

Semevskyi, V. Y. (1888). Krestianskyi vopros v Rossii v XVIII - v I polovine XIX vv. [The peasant question in Russia in the eighteenth - in the first half of the nineteenth centuries]: in 2 vol. S.-Peterburg, Vol. 1, 517 p. [in Russian]

Sliusarskyi, A. H. (1955). V. N. Karazin. Ego zhizn i obshchestvennaia deiatelnost [V. N. Karazin. His life and social activity]. Kharkov, 159 p. [in Russian]

Stanchev, M. H. (2005). Proiskhozhdenie V. N. Karazina: problem istoriohrafii i istochnikovedeniia [The origin of V. N. Karazin: problems of historiography and source studies]. Bulgarian Historical Review: Research Quarterly. Organ of the Inst. Of History at the Bulg. Acad. Of Sciences, 3-4, 203-215. [in Russian]

Trefilev, E. P. (1910). Vssylke: k biohrafii Vasiliia Nazarovicha Karazina [In exile: To the biography of Vasily Nazarovich Karazin]. Kharkov. 85 p. [in Russian]

Tykhoi, N. (1905). Politicheskie vozzreniia V. N. Karazina [The V. N. Karazin's political views]. Kharkov, 186 p. [in Russian]

Uzbek, O. A. (2002). Vasyl Karazin z rodu Karadzhi [Vasyl Karazin from the Karaji family]. Kharkiv: Maidan, 132 p. [in Ukrainian]

Venhlovskyi, S. (1990). Try areshty Karazina [Three arrests of Karazin]. Nauka i kultura. Shchorichnyk, 24, 86. [in Ukrainian]

Vovk, O. I. (2016). Postat Vasylia Karazina v istoriohrafii [The figure of Vasily Karazin in historiography]. Kharkiv : KhNU imeni V. N. Karazina, 328 p. [in Ukrainian]

Vovk, O. I. \& Kudelko, S. M. (2015). V. N. Karazin. Dialohy u chasi y prostori (doslidzhennia $i$ materialy) [V. N. Karazin. Dialogues in time and space (research and materials)]. Kharkiv: KhNU imeni V. N. Karazina, 272 p. [in Ukrainian]

The article was received on February 27, 2020. Article recommended for publishing 17/02/2021. 